\title{
Nuclear Bodies in Human Prostate with Special Reference to Appearance Rate
}

\author{
Masakuni Furusato, Yasushi Kikuchi, Shin Wakui, Tetsuro Wada*, \\ Izuru Matsumoto, Kensuke Joh, Ryoji Suzuki**, Yoshiko Yokoyama***, \\ Shigeo Aizawa and Eisei Ishikawa \\ Department of Pathology and *Department of Urology, Jikei University, \\ School of Medicine, Nishishinbashi, Minatoku, Tokyo 105, Japan, \\ **Department of Urology, Mito Red Cross Hospital, Sannomaru, Mito 310, \\ and *** Aoyama Gakuin University, Shibuya-ku, Tokyo 150, Japan
}

\begin{abstract}
The Nuclear Body Appearance Rate in seventeen human prostatic cases was statistically analyzed according to three lesion areas - the hyperplastic nodule, non-nodule and atrophic - in the secretory epithelium and basal cells. It was meaningfuly high in the secretory epithelium of the hyperplastic nodule, but not in the other two lesion areas. There was no meaningful result in basal cells.

Though there is a wide variety of reported data on the human prostate, particular care must be taken in analysis at the electron microscopic level, keeping in mind that even in a single specimen this organ has a notable variety of tissue changes. The Nuclear Body Appearance Rate reflects cellular hyperactivity although it does not have a specific known function at present.
\end{abstract}

Since the first discovery in 1960 of the nuclear body in calf tissue by De The, nuclear bodies in the cell nucleus of various cells and organs have been studied by many researchers $(2,8,9,10,11,14,16,17,22,25,29)$. At present, the nuclear body is taken to be one of several normal structures in the nucleus (1).

The electron microscope has been employed for observation and confirmation of this structure because of its size. Additionally, trials have been made to examine cell and tissue behavior by determination of the frequency of nuclear body positive nuclei per counted nuclei, or Nuclear Body Appearance Rate (N.B.A.R.) in electron microscopic sections $(5,8,9,12,21,22,23,25)$. As for the rate in the human prostate, Smetana first reported the appearance rate in 1979 (25). He found a rate of about $20.0 \%$ in the total nuclei he observed, although the fundamental data for obtaining this frequency were not shown. In 1981, Furusato first reported a definite appearance rate of $31.0 \%$ based on a total of 2269 nuclei when comparing prostatic hyperplasia to carcinoma (8). Ohtsuki presented an N.B.A.R. of $5.2 \%$ in 348 nuclei in hyperplastic lesions from cancer cases and also an N.B.A.R. of $5.6 \%$ in 285 nuclei in normal regions from cancer cases (22). It is clear that the facts listed above do not concur well, probably due to improperly concentrated sampling. In addition, the presence of two epithelial types, namely the secretory epithelium (S.E.) and basal cells (B.C.), have been completely neglected in previous reports. The major purpose of the present study is, therefore, to analyze in more precise detail the N.B.A.R. of the nuclear body in 
situ, with reference to the two kinds of epithelium from hyperplastic nodule, nonnodule, and atrophic lesions of the human prostate.

\section{MATERIALS AND METHODS}

The prostatic tissue was obtained in surgery for either transurethral resection or suprapubic total prostatectomy performed on 17 patients with benign prostatic hyperplasia. The tissue was first macroscopically separated into hyperplastic nodule and non-nodule areas. The nodules usually employed were 5 to $10 \mathrm{~mm}$ in diameter, and the center of the lesion was cut and fixed in $1.2 \%$ glutaraldehyde and osmium tetroxide. After dehydration by graded alcohol, the tissue was embedded in Epon 812 . In the blue section of the tissue, atrophic lesions were further distinguished from those of non-nodule areas and used for observation. Difficulty was encountered in obtaining all three different lesions from the same case, but in three cases we were successful.

After ultrathin sectioning the sections were doubly stained using lead citrate and uranyl acetate and observed on a Hitachi $\mathrm{H}-500 \mathrm{H}$ electron microscope. The nuclei were randomly selected and photographed in one section per block. At least three blocks per case were utilized.

The cells were classified as secretory epithelium or basal cell respectively at each of the three lesions. Then the number of nuclei which had nuclear bodies were counted. We then obtained the N.B.A.R. by dividing the number of nuclear body positive nuclei by the total number of counted nuclei. The data were then analyzed according to the variables of cell type and lesion area following the method of Minute Accumulation Analysis of the variance.

\section{RESULTS}

From one to three nuclear bodies occurred in a single nuclear body positive nucleus throughout the lesions. There were two kinds of nuclear bodies. The first one was made up of only a mass of very fine microfilaments of about 1.5 to $3.0 \mathrm{~nm}$ in diameter (Fig. 1). These had what are known as hollow, empty spaces between the nuclear body and the surrounding nuclear chromatin. The diameter was from about 0.5 to $1.0 \mu \mathrm{m}$. The second type of nuclear body had several dense granules in the central area of the above type of nuclear body, although this kind was rarely encountered (Fig. 2). The appearance rates for the secretory epithelium and the basal cells which were obtained for each individual case at the three different locations are listed in Tables 1, 2, and 3. A summary of the appearance rate for the secretory epithelium and the basal cells at the three different lesions is listed in Table 4.

According to Table 1, a total of 1,904 nuclei of the nodule area in 11 cases were observed; 428 nuclei were found to have the nuclear body, making an average appearance rate of $26.3 \%$. Nuclei of the secretory epithelium account for 1385 of the total, with 357 nuclear body positive nuclei. The appearance rate for the secretory epithelium alone was $28.0 \%$. The remaining 519 nuclei were those of basal cells, with 71 nuclear body positive nuclei, making an appearance rate of $13.5 \%$.

In a total of 863 nuclei of the non-nodular area from a total of 4 cases, the nuclei positive for the nuclear body account for 102. The average N.B.A.R. for these was $13.2 \%$. The number for the secretory epithelial nuclei was a total of 524, with 75 nuclear body positive nuclei. The appearance rate was $15.0 \%$. The basal cell nuclei account for 339 , with 27 nuclear body positive nuclei. Thus the appearance rate for 

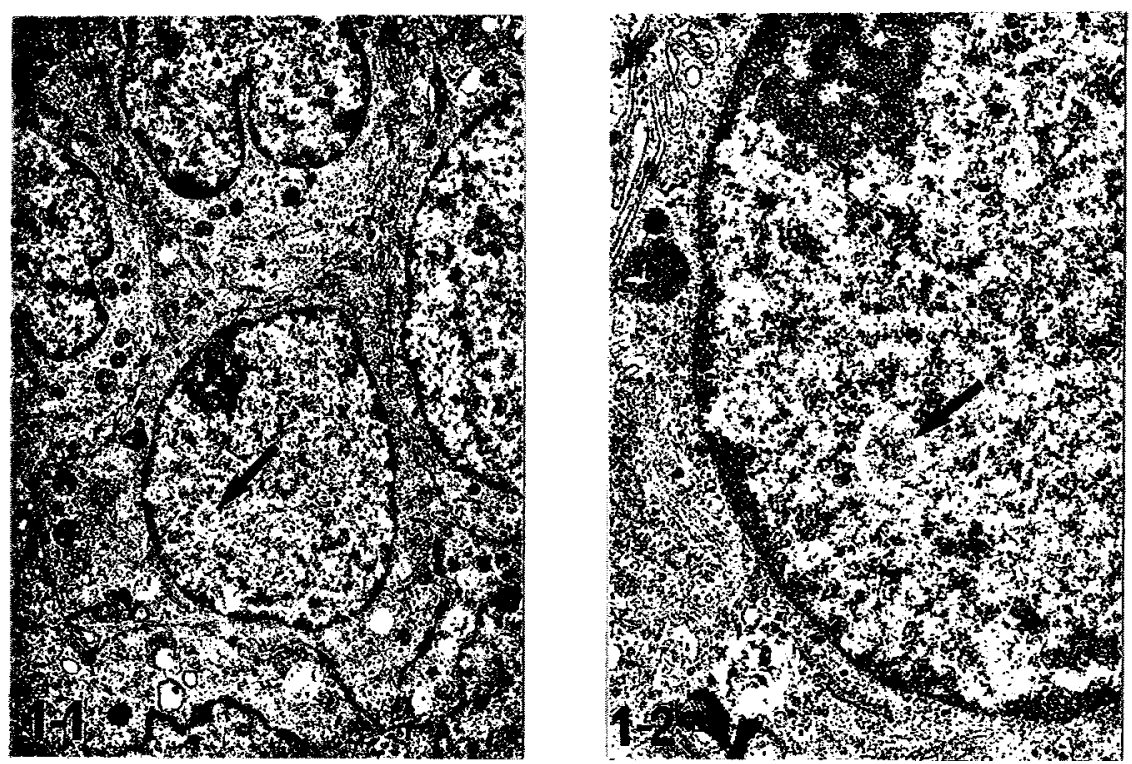

Fig. 1-1. Type-I nuclear body (arrow), within a hollow, is composed of a fine filamentous aggregation. Mag. $\times 5,300$

Fig. 1-2. High power view of Fig. 1-1. A nuclear body is shown at the arrow. Mag. $\times 13,400$
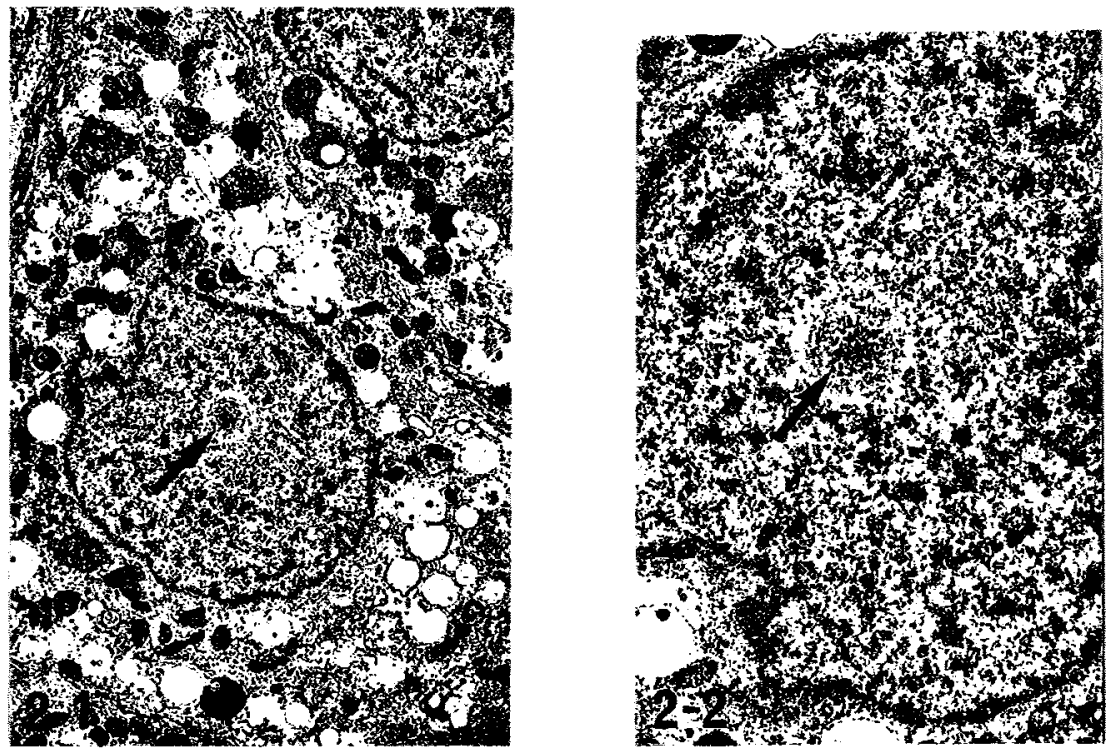

Fig. 2-1. A type-II nuclear body is shown at the arrow. Mag. $\times 5,300$

Fig. 2-2. In a high power view, aggregation of electron-dense granules is observed in the central area of a nuclear body (arrow). Mag. $\times 12,800$ 
TABLE 1. NUCLEAR BODY APPEARANCE RATE IN NODULE AREA

\begin{tabular}{|c|c|c|c|c|}
\hline & & (Secretory Epithelium) & (Basal Cell) & （Total Cell） \\
\hline Cases & Age & $\begin{array}{c}\text { Nucleus } 4 \text { Nuclear Body } \\
\text { /Total Nucleus }\end{array}$ & $\begin{array}{c}\text { Nucleus } \$ \text { Nuclear Body } \\
\text { /Total Nucleus }\end{array}$ & $\begin{array}{c}\text { Nucleus } \$ \text { Nuclear Body } \\
\text { / Total Nucleus }\end{array}$ \\
\hline 1. & 80 & $10 / 30$ & $2 / 13$ & $12 / \quad 43$ \\
\hline 2. & 65 & $8 / \quad 30$ & $0 / 0$ & $8 / 30$ \\
\hline 3. & 70 & $29 / 100$ & $10 / 52$ & $48 / 152$ \\
\hline 4. & 72 & $26 / 125$ & $10 / 59$ & $36 / 184$ \\
\hline 5. & 59 & $67 / 192$ & $11 / 42$ & $78 / 234$ \\
\hline 6. & 60 & $23 / 91$ & $0 / 8$ & $23 / \quad 99$ \\
\hline 7. & 67 & $68 / 238$ & $24 / 128$ & $92 / 366$ \\
\hline 8. & 47 & $23 / \quad 47$ & $0 / 0$ & $23 / 47$ \\
\hline 9. & 72 & $31 / 139$ & $9 / 55$ & $40 / 194$ \\
\hline 10 & 68 & $28 / 133$ & $8 / 77$ & $36 / 210$ \\
\hline 11. & 64 & $44 i 260$ & $7 / 85$ & $51 / 345$ \\
\hline & & $357 / 1385(28.0 \%)$ & $71 / 519(13.5 \%)$ & $428 / 1904(26.3 \%)$ \\
\hline
\end{tabular}

In 11 cases a total of 1904 nuclei were counted, with an average N.B.A.R. of $26.3 \%$. The average N.B.A.R. was $28.0 \%$ in the secretory epithelium and $13.5 \%$ in the basal cells.

TABLE 2. NuClEAR BODY APPEARANCE RATE IN NON-NODULE AREA

\begin{tabular}{|c|c|c|c|c|}
\hline & & (Secretory Epithelium) & （Basal Cell） & （Total Cell） \\
\hline Cases & Age & $\begin{array}{c}\text { Nucleus } 4 \text { Nuclear Body } \\
\text { /Total Nucleus }\end{array}$ & $\begin{array}{c}\text { Nucleus \& Nuclear Body } \\
\text { /Total Nucleus }\end{array}$ & $\begin{array}{c}\text { Nucleus } 4 \text { Nuclear Body } \\
\text { /Total Nucleus }\end{array}$ \\
\hline 1. & $?$ & $16 / 100$ & $0 / 20$ & $16 / 120$ \\
\hline 2. & 72 & $19 / 109$ & $6 / 55$ & $25 / 164$ \\
\hline 3. & 59 & $24 / 210$ & $1 / 166$ & $25 / 376$ \\
\hline \multirow[t]{2}{*}{4.} & 72 & $16 / 105$ & $20 / 98$ & $36 / 203$ \\
\hline & & $75 / 524(15.0 \%)$ & $27 / 339(8.0 \%)$ & $102 / 863(13.2 \%)$ \\
\hline
\end{tabular}

In 6 cases a total of 863 nuclei were counted with an average N.B.A.R. of $13.2 \%$. The average N.B.A.R. was $15.0 \%$ in the secretory epithelium and $8.0 \%$ in the basal cells.

was $8.0 \%$. These data are shown in Table 2 .

In the atrophic areas, a total of 1,617 nuclei were counted in a total of 7 cases, with 176 nuclear body positive nuclei. The average appearance rate for the total nuclei was $11.5 \%$. The secretory epithelial nuclei account for 1,239 , with 118 nuclear body positive nuclei. The appearance rate was $10.1 \%$. Fifty-eight nuclei out of the remaining 378 nuclei of the basal cells were found to be positive for the nuclear body: an appearance rate of $22.2 \%$. The data are shown in Table 3 . 
TABLE 3. NUCLEAR BODY APPEARANCE RATE IN ATROPHY AREA

\begin{tabular}{|c|c|c|c|c|}
\hline \multirow[b]{2}{*}{ Cases } & \multirow[b]{2}{*}{ Age } & \multirow{2}{*}{$\begin{array}{c}\text { (Secretory Epithelium) } \\
\text { Nucleus \& Nuclear Body } \\
\text { /Total Nucleus }\end{array}$} & (Basal Cell) & （Total Cell） \\
\hline & & & $\begin{array}{c}\text { Nucleus } \& \text { Nuclear Body } \\
\text { /Total Nucleus }\end{array}$ & $\begin{array}{c}\text { Nucleus } ₫ \text { Nuclear Body } \\
\text { /Total Nucleus }\end{array}$ \\
\hline 1. & 72 & $0 / 125$ & $26 / 41$ & $26 / 166$ \\
\hline 2. & 73 & $5 / 48$ & $0 / 0$ & $5 / 48$ \\
\hline 3. & 71 & $37 / 197$ & $2 / 72$ & $39 / 269$ \\
\hline 4. & 72 & $37 / 242$ & $11 / 70$ & $48 / 312$ \\
\hline 5. & 64 & $16 / 155$ & $12 / 112$ & $28 / 267$ \\
\hline 6. & 73 & $15 / 408$ & $5 / 44$ & $20 / 452$ \\
\hline 7. & 68 & $8 / \quad 64$ & $2 / 39$ & $10 / 103$ \\
\hline & & $118 / 1239(10.1 \%)$ & $58 / 378(22.2 \%)$ & $176 / 1617(11.5 \%)$ \\
\hline
\end{tabular}

In 7 cases a total of 1617 nuclei were counted, with an average N.B.A.R. of $11.5 \%$. The average N.B.A.R. in the secretory epithelium was $10.1 \%$ and $22.2 \%$ in the basal cells.

TABLE 4. SUMMARY OF APPEARANCE RATE OF NUCLEAR BODY OF SECRETORY EPITHELIAL

\begin{tabular}{|c|c|c|c|}
\hline & NUCLEUS AND BAS & CELL NUCLEUS IN THREE LE & ESION AREAS \\
\hline & (Secretory Epithelium) & (Basal Cell) & （Total Cell） \\
\hline Locations & $\begin{array}{l}\text { Nuclear Body Positive } \\
\text { Nucleus/Total Nucleus }\end{array}$ & $\begin{array}{l}\text { Nuclear Body Positive } \\
\text { Nucleus/Total Nucleus }\end{array}$ & $\begin{array}{l}\text { Nuclear Body Positive } \\
\text { Nucleus/Total Nucelus }\end{array}$ \\
\hline Nodule & $357 / 1385(28.0 \%)$ & $71 / 519(13.5 \%)$ & $428 / 1904(26.3 \%)$ \\
\hline Non-Nodule & $75 / 524(15.0 \%)$ & $27 / 339(8.0 \%)$ & $102 / 863(13.2 \%)$ \\
\hline \multirow[t]{2}{*}{ Atrophy } & $118 / 1239(10.1 \%)$ & $58 / 378(22.2 \%)$ & $176 / 1617(11.5 \%)$ \\
\hline & & Average & $706 / 4384(17.0 \%)$ \\
\hline
\end{tabular}

The total number of nuclei counted in this study was 4,384, out of which 706 have a nuclear body: an appearance rate of $17.0 \%$. The summary is shown in Table 4.

The statistical analysis of the variance was carried out on the basis of the mean percentage and the distribution pattern of the appearance rate for the two types, the secretory epithelium and the basal cells, at the three different lesion areas. The data for analysis of the variance in the N.B.A.R. of these two factors at the three lesions are shown in Tables 5 and 6 . A diagram of the results showed meaningful differences both in the mean percentage and the distribution of the appearance rate for the secretory epithelial nucleus between the nodule and the other two lesions. (Tables 5-1, 5-2, and Fig. 3) There was no meaningful difference for the non-nodule versus the atrophic lesion. Moreover, analysis of the basal cell nuclei failed to show any meaningful differences for any of the three lesions. (Tables 6-1, 6-2 and Fig. 4)

There was no correlation found between the patient's age and the appearance rate. 
TABLE 5-1. DIAGRAM OF THE ANALYSIS ON THE VARIANCE OF NUCLEAR BODY APPEARANCE RATE OF SECRETORY EPITHELIAL NUCLEUS IN THREE LESION AREAS

\begin{tabular}{|c|c|c|c|c|c|c|}
\hline \multicolumn{2}{|c|}{ Source } & $f$ & $\mathbf{S}$ & v & & \\
\hline \multirow{12}{*}{$\mathbf{R}$} & $R^{\prime}$ & 2 & 0.2597 & $0.1299^{\circ}$ & f : & degree of freedom \\
\hline & within $R^{\prime}$, & 10 & 3.4910 & $0.3497^{\circ}$ & $\mathrm{v}:$ & variance \\
\hline & within $\mathbf{R}_{2}{ }_{2}$ & 3 & 0.6000 & $0.2000^{\circ}$ & F : & variance ratio \\
\hline & within $R^{\prime}{ }_{3}$ & 6 & 6.2857 & $1.0476^{\circ}$ & $\begin{array}{l}\text { e } \\
\text { S : }\end{array}$ & $\begin{array}{l}\text { error } \\
\text { sum of percentage }\end{array}$ \\
\hline & $\left(e_{1}\right)$ & (21) & $(10.6364)$ & $(0.5065) * *$ & $* *:$ & $1 \%$ significant \\
\hline & $\omega$ & 9 & 20.2727 & $2.2525 \pi *$ & $\begin{array}{r}\circ: \\
\omega\end{array}$ & $\begin{array}{l}\text { pooling } \\
\text { division of } N \text { B }\end{array}$ \\
\hline & $\mathbf{R}^{\prime} \times \omega$ & 18 & 0.9156 & $0.0509^{\circ}$ & $\mathbf{R}^{\prime}:$ & between $R_{1}^{\prime}, R_{2}^{\prime}, R_{3}^{\prime}$ \\
\hline & within $R^{\prime} \times \omega$ & 90 & 7.0546 & $0.0784^{\circ}$ & $\begin{array}{l}\mathrm{R}_{1}{ }_{1}: \\
\mathrm{R}_{2}:\end{array}$ & $\begin{array}{l}\text { nodule } \\
\text { non nodule }\end{array}$ \\
\hline & within $R_{2}^{\prime} \times \omega$ & 27 & 1.9000 & $0.0704^{\circ}$ & $\mathrm{R}_{3}^{\prime}:$ & atrophy \\
\hline & within $\mathbf{R}^{\prime} \times \omega$ & 54 & 2.8571 & $0.0529^{\circ}$ & & \\
\hline & $\left(\mathbf{e}_{2}\right)$ & (189) & (12.7273) & $(0.0673)^{\prime}$ & & \\
\hline & Total & 219 & 43.6364 & & & \\
\hline
\end{tabular}

TABLE 5-2. Distribution OF AVERAGE DATA OF NUCLEAR BODY APPEARANCE RATE OF SECRETORY EPITHELIAL NUCLEUS IN THREE LESION AREAS

\begin{tabular}{|c|c|c|c|c|c|c|c|c|c|c|}
\hline & $\omega_{1}$ & $\omega_{2}$ & $\omega_{3}$ & $\omega_{4}$ & $\omega_{5}$ & $\omega_{6}$ & $\omega_{7}$ & $\omega_{8}$ & $\omega_{9}$ & $\omega_{10}$ \\
\hline $\mathbf{R}^{\prime}$ & 1.000 & 1.000 & 1.000 & 0.909 & 0.636 & 0.454 & 0.273 & 0.091 & 0.091 & 0.091 \\
\hline$(\omega \mathrm{i}-\omega \mathrm{i}+1)$ & 0.000 & 0.000 & 0.091 & 0.273 & 0.182 & 0.181 & 0.182 & 0.000 & 0.000 & 0.091 \\
\hline $\mathbf{R}^{\prime}$ & 1.000 & 1.000 & 0.750 & 0.000 & 0.000 & 0.000 & 0.000 & 0.000 & 0.000 & 0.000 \\
\hline$(\omega \mathrm{i}-\omega \mathrm{i}+1)$ & 0.000 & 0.250 & 0.750 & 0.000 & 0.000 & 0.000 & 0.000 & 0.000 & 0.000 & 0.000 \\
\hline $\mathbf{R}^{\prime}$ & 1.000 & 0.713 & 0.429 & 0.143 & 0.000 & 0.000 & 0.000 & 0.000 & 0.000 & 0.000 \\
\hline$(\omega \mathrm{i}-\omega \mathrm{i}+1)$ & 0.287 & 0.284 & 0.286 & 0.143 & 0.000 & 0.000 & 0.000 & 0.000 & 0.000 & 0.000 \\
\hline & & $\begin{array}{c}\omega_{1}: N \\
\omega_{2}: N \\
l \\
\omega_{10}: N\end{array}$ & $\begin{array}{l}\text { B. A. R, } \\
\text { B. A. R. }\end{array}$ & $\begin{array}{r}0 \sim 5 \\
\sim 10 \\
50 \sim 55\end{array}$ & $\begin{array}{l}\% \\
\%\end{array}$ & & & & & \\
\hline
\end{tabular}

Analysis was by Minute Accumulating Analysis.

\section{DISCUSSION}

Bouteille classified nuclear bodies morphologically into five types (2). Most of the nuclear bodies we observed were categorized as the first type. Smetana classified this type of nuclear body as filamentous because of its morphological characteristics (25). We saw, but only rarely, another type of nuclear body which has dense granules sized from 10 to $30 \mathrm{~nm}$ in diameter at the central area of the above type I nuclear body. The latter type is equivalent to the one classified as type II by Bouteille. Similar findings in the human prostate have also been confirmed by Smetana (25) and 
TABLE 6-1. DiAgraM OF THE ANALYSIS ON THE VARIANCE OF NUClEAR BODY APPEARANCE RATE OF BASAL CELL IN THREE LESION AREAS

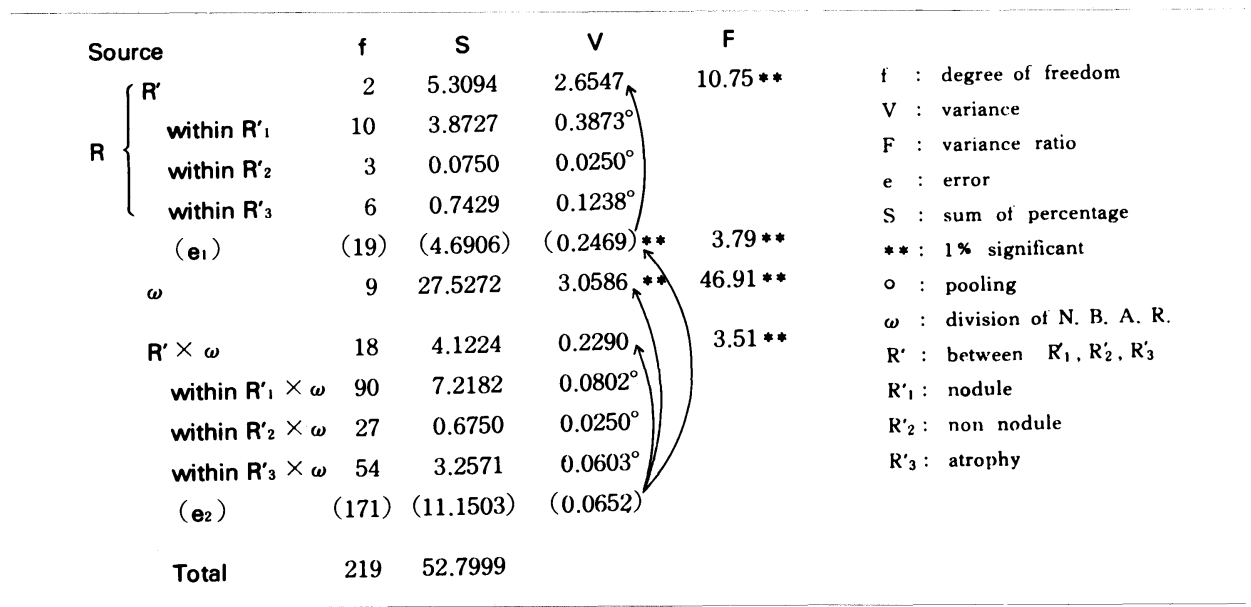

TABLE 6-2. Distribution OF AVERAGE DATA OF NUClEAR BODY APPEARANCE RATE OF BASAL CELL IN THREE LESION AREAS

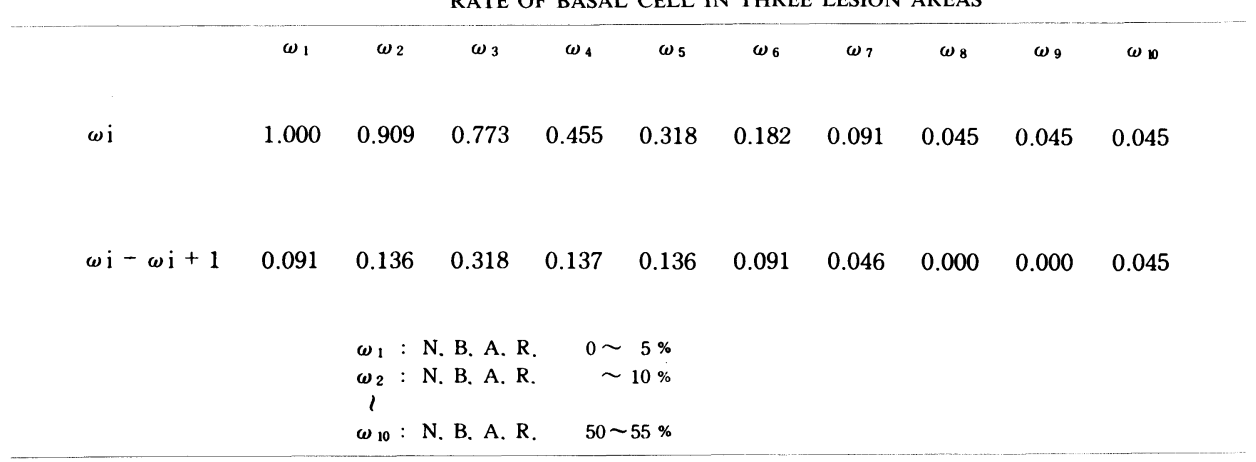

Analysis was by Minute Accumulation Analysis.

Ohtsuki (22). In addition, Ohtsuki recognized nuclear bodies corresponding to Bouteille's type III, but no such finding was confirmed in our study.

The frequency of occurrence of the nuclei which are positive for the nuclear body in the total number of nuclei from the selected cells and/or tissue can be calculated as a Nuclear Body Appearance Rate (N.B.A.R.) for those nuclear bodies. It has also been refered to as a nuclear body profile by several researchers $(12,29)$.

In the human prostate, Smetana reported the figure of $20.0 \%$ for the appearance rate although his fundamental data for obtaining this rate were not published (25). Furusato et al. reported a rate of $31.0 \%$ in 2,269 nuclei for three cases which showed a high appearance rate (8). Ohtsuki presented an N.B.A.R. of $5.2 \%$ in 384 nuclei in hyperplastic lesions from cancer cases and also an N.B.A.R. of $5.6 \%$ in 285 nuclei from the normal area in prostatic tissue. The data for hyperplastic cells shown by Ohtsuki were particularly low.

In this report, with a comparison of the appearance rates for three different lesion areas - the hyperplastic nodule, non-nodule and atrophic - and an analysis of the variance, it has been shown that there are meaningful differences in data for both the 


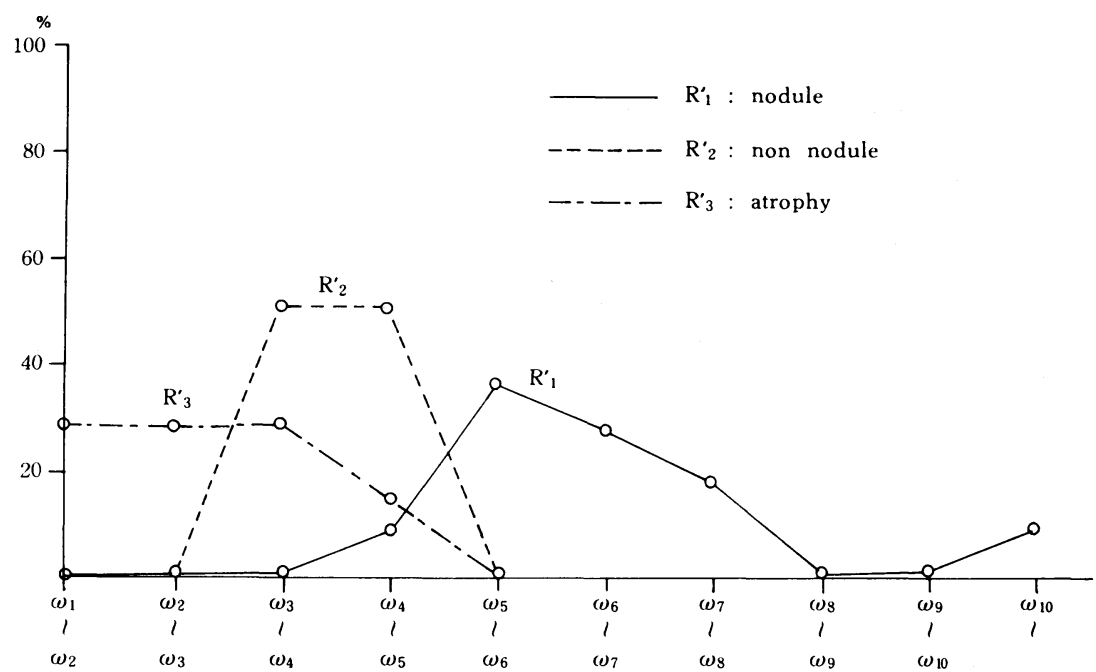

Fig. 3. Distribution diagram of N.B.A.R. of secretory epithleial nucleus in: R'1, nodule; R'2, non-nodule; and R'3, atrophic areas. There is a definite difference in N.B.A.R. between the nodule and the other two lesion areas.

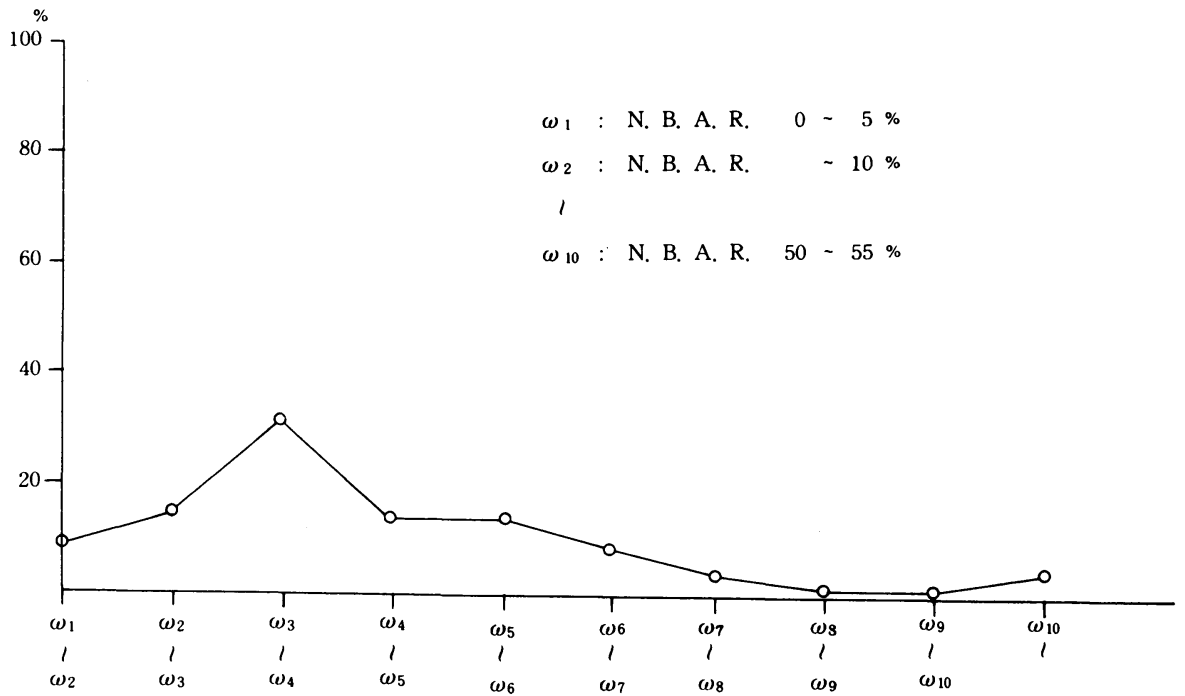

Fig. 4. Distribution diagram of N.B.A.R. of the basal cell nucleus in the three lesion areas. There is no meaningful difference in the N.B.A.R. between the three lesion areas.

mean N.B.A.R. and the distribution pattern of the N.B.A.R. in the secretory epithelial nucleus, especially for the nodule lesion as opposed to the other two lesions.

Although the two cell type classification was not made in previous reports, what can be deduced from the above data is that there might have been concentrated sampling of the nodule area by those who obtained high appearance rates. Likewise, the lowest percentages show the possibility of there having been a concentration of 
sampling in the non-nodule and/or atrophic areas. These conclusions can be seen in Padykula's context of the nuclear bodies being "rare" cellular components, and it is this scarceness which creates a sampling problem for transmission electron microscopy (23). We would like to call for additional care in looking at nuclear bodies, particularly for paying attention to the handling of an organ like the human prostate, in which various changes of tissue (such as hyperplasia, normal areas and atrophy) commonly occur in the same case when the patient is over 40 years of age.

There have been experimental reports relating the change of appearance rate for the nuclear body in various kinds of cells and tissues to biological changes $(5,12,14,23$, 24, 27, 28). Ishii found that an increase of the N.B.A.R. in the mouse plasma cell parallels the elevation of plasma immunoprotein (12). Padykula also found that changes of N.B.A.R. parallel endometrial proliferation when induced by estradiol administration to the immature rat (23). As has been proposed by many authors, nuclear bodies of the human prostate appear to be related to the cell proliferation gradient, and the results for the secretory epithelium should be considered from this viewpoint. There was, however, no appreciable correlation in the N.B.A.R. of the basal cell between any of the three lesion areas. As a functional participant of the prostatic epithelium, the basal cell is believed to be the source of the epithelial cell (4), and is also called a reserve cell. Therefore, one could assume a high N.B.A.R. in the nucleus of the basal cell by simply applying the results obtained from the secretory epithelium to the basal cell. Results contrary to this reasoning were actually obtained. The phenomenon of the N.B.A.R. difference between the B.C. and the S.E. may relate to some as yet unspecifiable biological function. As is most often proposed, the N.B.A.R. is to be given a wide spectrum of roles with regard to the cell nucleus. In this context the N.B.A.R. would simply indicate the active metabolic status of the cell. This seems to be the most likely hypothesis and appears to suit the results we obtained.

Acknowledgments. This work was supported by Haraguchi Memorial Cancer Research Fund.

\section{REFERENCES}

1. Arias, I., H. Popper, D. Schachter and D.A. Shafrits. Liver biology and pathobiology, Raven Press, New York, p. 76, 1982

2. Bouteille, M., S.R. Kalifat and J. Delarue. Ultrastructural variations of nuclear bodies in human diseases. J. Ultrastruct. Res. 19, 474-486, 1967

3. De The, G. and W. Bernhard. Bull. Assoc. Franc. Etude Cancer 45, 570, 1960

4. Dermer, G.B. Basal cell proliferation in benign prostatic hyperplasia. Cancer 41, 1857-1862, 1978

5. Domont, A and A. Robert. Ultrastructure of complex nuclear bodies produced experimentally in hamster peritoneal macrophages. J. Ultrastruct. Res. 36, 483-492, 1971

6. Dupuy-Coin, A.M., P. Lazan, S.R. Kalifat and M. Bouteille. A method of quantification of nuclear bodies in electron microscopy. J. Ultrastruct. Res. 27, 244-249, 1969

7. Fisher, E.R. and W. JefFreY. Ultrastructure of human normal and neoplastic prostate; with comments relative to prostatic effects of hormonal stimulation in the rabbit. Am. J. Clin. Pathol. 44, 119-134, 1965

8. Furusato, M., Y. Yamaguchi, H. Yamashita, S. Kakimoto, M. Tanaka, T. Machida and E. IshiKaWA. Nuclear bodies in human prostatic epithelium. Proceedings of the Japanese Cancer Association: The 40th Annual Meeting. p. 302, 1981

9. Furusato, M., Y. Yamaguchi and N. KaWaguchi. The appliance of electron microscopy 
in disease of the urogenital Tract (10): prostatic carcinoma. Rinsho Hinyoki. 36, 922-931, 1982, in Japanese.

10. Henry, K. and V. Petts. Nuclear bodies in human thymus. J. Ultrastruct. Res. 27, 330-343, 1969

11. IDA, T. Ultrastructural study of nuclear bodies in the human uterine cervical squamous carcinoma II. Conglomerate type and clusters of the nuclear bodies. J. Clin. Electron Microsc. 17, 251-267, 1984

12. IsHII, Y., M. MORI and T. ONOE. Electron microscopic study of nuclear bodies in plasma cells of mouse lymph nodes during the primary immune response. J. Electron Microsc. 20, 182-190, 1971

13. Karasek J., A. Herdlicka and K. Smetana. Studies on the nuclear and nucleolar ultrastructure in differentiation and differentiated human sebaceous cells. J. Ultrastruct. Res. 42, 234-243, 1973

14. Karasek, J., A. Herdlicka and K. Smetana. Epidermal globular nuclear inclusion; an ultrastructural cytochemical study. J. Ultrastruct. Res. 56, 15-20, 1976

15. Karasek, K., A. Herdlicka and K. Smetana. Studies on the nuclear and nucleolar ultrastructure in differentiating and differentiated human sebaceous cells. J. Ultrastruct. Res. 42, 234-243, 1977

16. Kierszenbaum, A.L. Relationship between nuclear bodies in human mixed salivary tumors. J. Ultrastruct. Res. 29, 459-469, 1969

17. KING, N.W. and L.V. MiLindiz. The ultrastructure of herpesvirus saimiri-induced lymphoma in cottontopped marosets. Lab. Invest. 26, 682-693, 1972

18. KuHN, C. Nuclear bodies and intranuclear globulin inclusions in Waldenstrom's macroglobulinemia. Lab. Invest. 17, 404-415, 1967

18. Monneron, A. and W. Bernhard. Fine structural organization of the interphase nucleus in some mammalian cells. J. Ultrastruct. Res. 27, 266-288, 1969

20. MoRI, M and T. ONOE. An electron microscopic study on the formation of intranuclear inclusions. J. Electron Microsc. 16, 137-142, 1967

21. NAGAO, T. Ultrastructural study of nuclear bodies in the human cervical squamous carcinoma. J. Clin. Electron Microsc. 15, 151-168, 1982

22. Ohtsuki, Y and T. Akagi. Fine structure of nuclear bodies observed in human prostatic hyperplasia and carcinoma. J. Clin. Electron Microsc. 15, 105-112, 1982

23. Padykula, H.A.M. Fitzgerald, J.H. Clark and J.W. Hardin. Nuclear bodies as structural indications of estrogenic stimulation in uterine luminas epithelial cells. Anat. Rec. 201, 679-696, 1981

24. Patrizi, G and J.N. Middelkamp. In vivo and in vitro demonstration of nuclear bodies in vaccinia infected cells. J. Ultrastruct. Res. 28, 275-287, 1969

25. Smetana, K., F. Gyorky, P. Gyorky and H. Buch. Compact filamentous bodies of nuclei and nucleoli of human prostate gland. Exp. Cell Res. 64, 133-139, 1971

26. Tanami, Y., N. Ohwada, Y. Nagao, M. Ohwada, H. Hagiwara and T. Tsukagoshi. Morphometrical estimation of real size distribution and average number of nuclear bodies per nucleus in human uterine cervical squamous cancer cells. J. Clin. Electron Microsc. 17, 237-250, 1984

27. Vagner-Capodano, A.M., J. Manchamp, A. Stahl and S. Lissitzky. Nucleolar budding and formation of nuclear bodies in cultured thyroid cells stimulated by thyrotropin, dibutyl cyclic AMP and prostaglandin, E2. J. Ultrastruct. Res. 70, 37-51, 1980

28. Vagner-Capodano, A.M., M. Bouteille, A. Stahl and S. Lissitzky. Nucleolar ribonucleoprotein release into the nucleoplasm as nuclear bodies in cultured thyrotropin-stimulated throid cells: autoradiographic kinetics. J. Ultrastruct. Res. 78, 13-25, 1982

29. Weber, A.F. and P.F. StePHEN. Nuclear bodies: their prevalence, location and ultrastructure in calf. Science 141, 912-913, 1963 